\title{
. \\ Cancer selective cytotoxicity of Sida acuta extracts on Artemia salina and human breast adenocarcinoma cells
}

\author{
Ramasamy Elankanni', Devanga Ragupathi Naveen Kumar ${ }^{2}$ and \\ Rangasamy Ashok Kumar ${ }^{1 *}$
}

'Department of Zoology, Government Arts College, Dharmapuri - 636705, Tamil Nadu, India. 2Department of Chemical and Biological Engineering, The University of Sheffield, Sheffield - S1 3JD, United Kingdom

Received: October 15, 2020 Revised: February 9, 2021 Accepted: February 13, 2021 Published: February 24, 2021

*Corresponding Author: R. Ashok Kumar E-mail: rangasamyashok@ gmail.com

\begin{abstract}
Cancer is one of the dreaded diseases and is the foremost basis of morbidity and death worldwide. The interests in the use of plants or plant-derived compounds are increasing recently due to their promising results in chemoprevention. The present study investigates the anti-cancer potential of Sida acuta, a traditionally well-known medicinal plant. Accordingly the methanol (SAM) and aqueous (SAA) extracts of Sida acuta, were examined against Artemia salina nauplii for toxicity and on human breast adenocarcinoma cell lines (MDA-MB-231 and MCF-7) for cytotoxic and apoptotic properties. Both the extracts, SAM and SAA exhibited higher toxicity towards Artemia salina. Interestingly, the extracts exhibited minimal cytotoxicity in normal cells (VERO) than in human breast cancer cells (MDA-MB-23l and MCF-7). The highly active SAA effectively induced apoptosis in both the cells (MDA MB 231 and MCF-7) showing 17.81\% and 4.27\% of late apoptotic cells and $27.14 \%$ and $37.32 \%$ of early apoptotic cells, respectively. Most of the drugs being developed from plant sources had landed successfully in clinical trials. In conclusion, the observations clearly suggest that SAA may have possible therapeutic potential against human breast cancer-derived diseases specifically against ER-positive breast cancer.
\end{abstract}

KEYWORDS: Sida acuta, Artemia salina, human breast cancer, MDA-MB-231, MCF-7, apoptosis, chemoprevention.

\section{INTRODUCTION}

Cancer, standing second to the cardiovascular disease, is one of the deadliest diseases that devour human life globally. The anticancer properties of plants have been recognized for centuries. According to $\mathrm{WHO}$, few countries yet predominantly rely on traditional herbal medicines for treating their ailments. Of the available natural resources on the earth, only a small proportion was analysed scientifically for their potent therapeutic effects (Borris, 1996). Officially, the National Cancer Institute (NCI) had reported reproducible anticancer activity for 3000 species among the 35,000 screened plants (Desai et al., 2008). Sida acuta belongs to Malvaceae family and has been documented as a common weed plant. It was well known for its medicinal uses. A decoction of the whole plant has been used as a treatment for fevers. The plant leaves were also believed to have antiinflammatory potential. Alkaloids (cryptolepine, ephedrine and vasicine), saponosides, coumarins, steroids, phenolic compounds such as scopoletin, loliolid, 4-ketopinoresinol, evofolin-A and B, polyphenol, sesquiterpene, tannins and flavonoids were the few phytochemical compounds identified in this plant (Benjumea et al.,2016). Moreover, S. acuta was previously reported for its activity against BT-549 breast adenocarcinoma (Fadeyi et al., 2013) and human hepatoma cells (HepG-2) (Pieme et al., 2010). Based on the available literature evidence, the anticancer efficacy of $S$. acuta extracts (aqueous and methanol) were evaluated further in detail to support available literature.

\section{MATERIALS AND METHODS}

\section{Plant Materials}

The healthy plants of S. acuta were gathered from its natural habitat from Indur village of Dharmapuri district (Tamil Nadu, India). A voucher specimen (GACDPISAl) was preserved in the laboratory as reference. The whole plants were dried in shade and coarsely powdered in a mechanical mixer-grinder.

\section{Preparation of Extracts}

The plant powder obtained was subjected to hot extraction using a soxhlet apparatus with methanol and water as solvents in the

Copyright: (C) The authors. This article is open access and licensed under the terms of the Creative Commons Attribution License (http://creativecommons.org/licenses/by/4.0/) which permits unrestricted, use, distribution and reproduction in any medium, or format for any purpose, even commercially provided the work is properly cited. Attribution — You must give appropriate credit, provide a link to the license, and indicate if changes were made. 
ratio of 1:6 [sample $(\mathrm{g})$ : solvent $(\mathrm{ml})]$. The resulting crude extracts were further concentrated to dryness in a rotavapor R-215 (BUCHI Labortechnik AG, Switzerland) under reduced pressure $(72 \mathrm{mbar})$ at $40{ }^{\circ} \mathrm{C}$. Further, the crude extracts were stored at room temperature in a vacuum desiccator until further use. The extracts were named as Sida acuta aqueous (SAA) and Sida acuta methanol (SAM).

\section{Brine Shrimp Lethality Assay (BSLA)}

Brine shrimp, Artemia salina nauplii was used as a preliminary model organism to evaluate the toxic effects of the plant extracts (Meyer et al., 1982). The eggs of the shrimp were obtained from STORI Salt Lake Artemia Cysts, Fish Cave Seller, Howrah, WB, India and kept at $4{ }^{\circ} \mathrm{C}$ in a refrigerator. The $A$. salina cysts were hatched by sprinkling $1 \mathrm{~g}$ of the cysts into a glass container (1 L capacity) containing sterile artificial sea water $(38 \mathrm{~g}$ of sea salt is dissolved in 1 litre of sterile water) and incubating them for 24 hrs under strong aeration and continuous light regime at room temperature $\left(25-29^{\circ} \mathrm{C}\right)$. The freshly hatched pink-coloured free-swimming nauplii were collected in a small container from the bottom of the hatching vessel and used for the bioassay. Different dilutions of the plant extracts were prepared by dissolving $20 \mathrm{mg}$ of the methanol and aqueous plant extracts in $2 \mathrm{~mL}$ of suitable solvents (stock solution) and further diluted to give a series of concentrations such as 1000, 100, 10, and lppm ( $\mu \mathrm{g} / \mathrm{ml})$ (Mclaughlin \& Rogers, 1998).

The experiment was performed by adding $0.5 \mathrm{ml}$ of the chosen concentration of the plant extracts with $4.5 \mathrm{ml}$ of sterile seawater in a watch glass and left undisturbed for 24hrs under constant illumination of florescent lamp. After 24hrs, using a hand lens, the numbers of dead and alive nauplii were recorded. If the larvae didn't display any movement during several seconds of observation, it is considered as dead. The experiments were conducted in triplicates for each dose along with a solvent and a negative control. Percentage of mortality was calculated by the following formula: = No. of dead nauplii/ Total No. of nauplii $\times 100$. Probit regression analysis was used to calculate $\mathrm{LC}_{50}$ values (Finney, 1971) at $95 \%$ confidence intervals.

\section{Cell lines and maintenance}

The cell lines (MDA-MB-231, MCF-7 and VERO) were obtained from National Centre for Cell Sciences, Pune, India and maintained in their respective medium with $10 \%$ fetal bovine serum [MDA-MB-231 cells in L-15 (Leibovitz's) culture medium without 5\% $\mathrm{CO}_{2}$; MCF-7 and VERO cells in Minimum essential medium (MEM) (Eagle) with Non-essential amino acids and $5 \% \mathrm{CO}_{2}$ ] in a humidified atmosphere at $37^{\circ} \mathrm{C}$. The cell lines were maintained with regular passaging in their growing phase at $70 \%$ confluency.

\section{Cytotoxicity Assay}

This study used the MTT assay (Mosmann, 1983) with slight modifications to study the cytotoxicity of the selected plant extracts. Briefly, the cells were seeded in a 96- well plate at a concentration of 10,000 cells from column 2-11 and each well were made to $200 \mu$ with respective fresh medium. Columns 1 and 12 were added with $200 \mu$ l of culture medium alone. The plate was sealed from all sides and was kept for incubation at $37^{\circ} \mathrm{C}$ in a humidified atmosphere. After the incubation period of 24 hours the existing culture media was decanted and $200 \mu \mathrm{l}$ of media containing different concentrations of plant extracts $(12.5,25,50,100,200 \mu \mathrm{g} / \mathrm{ml})$ were added. After 24 hours, the extract medium was removed and fresh medium was added along with $10 \mu \mathrm{l}$ MTT reagent to achieve a final concentration of $0.45 \mu \mathrm{g} / \mathrm{ml}$. The plate was then covered with aluminium foil and incubated at $37{ }^{\circ} \mathrm{C}$ for $3-4$ hours. After incubation, the MTT medium was removed and each well was added with 100 $\mu \mathrm{l}$ of Solubilization solution (DMSO) to dissolve the formazan crystals. Absorbance was read at $570 \mathrm{~nm}$ in a Microplate Reader (Dynex Opsys MRTM, Dynex Technologies, VA, USA) having $630 \mathrm{~nm}$ as reference filter. The wells comprising cells without treatment served as the control. Percentage cytotoxicity of the extracts was calculated by using the formula: A $\mathrm{A} / \mathrm{A}_{\mathrm{c}} \times 100$. Where, $\mathrm{A}_{\mathrm{c}}$ is the Absorbance of control cells and $\mathrm{A}$ is the absorbance of the extract treated cells. The linear regression equation $(\mathrm{Y}=\mathrm{Mx}+\mathrm{C})$ is used to calculate the $\mathrm{IC}_{50}$ value. Here, $\mathrm{Y}=50, \mathrm{M}$ and $\mathrm{C}$ values were derived from the viability graph.

\section{Apoptosis Assay}

The apoptosis inducing ability of the extract (SAA) was analysed by Annexin-V/PI Flow Cytometry. The cells, MDA-MB-231 and MCF-7 were seeded in a 6-well plate at a density of $3 \mathrm{x}$ $10^{5}$ cells $/ 2 \mathrm{ml}$ and incubated at $37^{\circ} \mathrm{C}$ in a $\mathrm{CO}_{2}$ incubator. The existing medium was removed after 24 hours and the cells were treated with required concentration of the plant extract $\left(\mathrm{IC}_{50}\right.$ value obtained from MTT assay). The medium in the control wells were replenished by fresh medium without extract. After the treatment hours, the cells were harvested directly in to the polystyrene centrifuge tubes $(12 \times 75 \mathrm{~mm})$ after treating with trypsin-EDTA solution $(200 \mu \mathrm{l})$ and centrifuged at $300 \mathrm{x} \mathrm{g}$ at $25^{\circ} \mathrm{C}$. The cells were washed twice with PBS and $5 \mu$ of FITC Annexin- $V$ was added. Further, gently vortexed and incubated in dark at RT $\left(25^{\circ} \mathrm{C}\right)$ for 15 minutes. Subsequently, the cells were treated with $5 \mu \mathrm{l}$ of PI and $400 \mu \mathrm{l}$ of $1 \mathrm{X}$ Binding Buffer and analysed immediately using BD FACS Calibur (San Jose, CA, USA) after gentle vortex. Camptothecin (Cat No: C9911, Sigma) was used as a standard control.

\section{Statistical Analysis}

All the experiments were carried out in triplicates. For each assay, data were presented as mean \pm SD from three independent experiments $(n=3)$. One-way ANOVA was used to perform all the statistical analyses and significant differences between groups were determined at $\mathrm{P}<0.05$. The results were analysed using correlation to evaluate relationships between experimental parameters and Student's t-test $(\mathrm{P}<0.05)$ is used to test the significance. Statistical and graphical evaluations were done using Microsoft Excel 2007 (Roselle, IL, USA), GraphPad Prism 5.0 (San Diego, CA, USA) and MATLAB ver. 7.0 (Natick, MA, USA). 


\section{RESULTS}

\section{Yield of Extracts}

The whole plant powder $(50 \mathrm{gm})$ of $S$. acuta up on hot extraction with methanol yielded $9 \mathrm{gm}$ (percentage extract yield: $18 \%$ of dry weight) of crude extract (SAM). Similarly, sequential hot aqueous extraction of the powder yielded $8 \mathrm{gm}$ (percentage extract yield: $16 \%$ of dry weight) of crude extract (SAA).

\section{Brine Shrimp Lethality Assay}

Both aqueous and methanol extracts of $S$. acuta exhibited mortality against the treated Artemia nauplii (Table 1 and 2). Figure $1 \& 2$ depicts the percentage mortality versus concentration of plant extracts for $S$. acuta whole plant aqueous and methanol extracts.

\section{Cytotoxicity Assay}

In this study, two extracts (SAA \& SAM) were evaluated using MTT assay to check the cytotoxicity on MDA-MB-231, MCF-7 and VERO cell lines (Figure 3). SAA exhibited lower $\mathrm{IC}_{50}$ values, 50.05 and $22.07 \mu \mathrm{g} / \mathrm{ml}$ when compared to SAM, 184.93 and $94.81 \mu \mathrm{g} / \mathrm{ml}$ in MDA-MB-231 and MCF-7 cells respectively.

\section{Apoptosis Assay}

In the cytotoxicity analysis, SAA exhibited maximum cytotoxicity on the cell lines tested. Hence, it was subjected to cell cycle analysis on MDA-MB-231 and MCF-7 cells. Accordingly, the Annexin-V/PI expression analysis of SAA against MDA MB 231 (Figure 4) and MCF-7 cells (Figure 5) showed

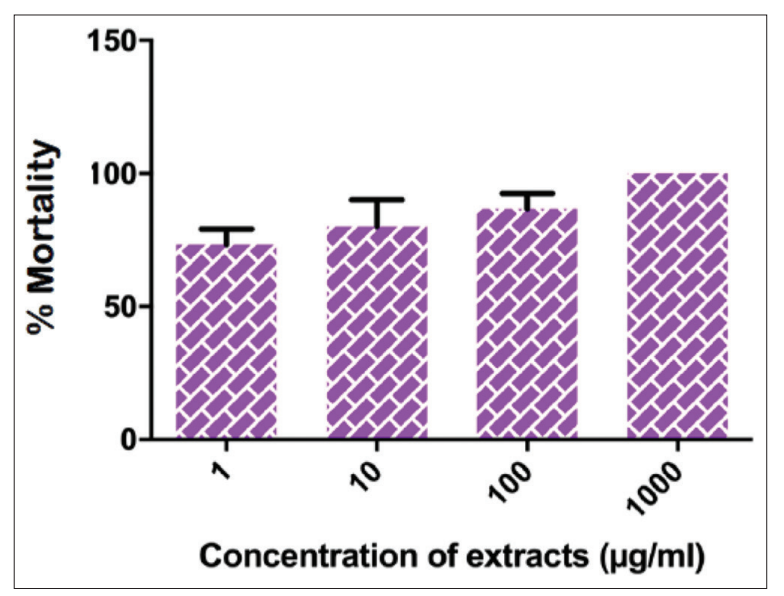

Figure 1: Percentage mortality of Sida acuta whole plant aqueous extract (SAA) on $A$. salina nauplii

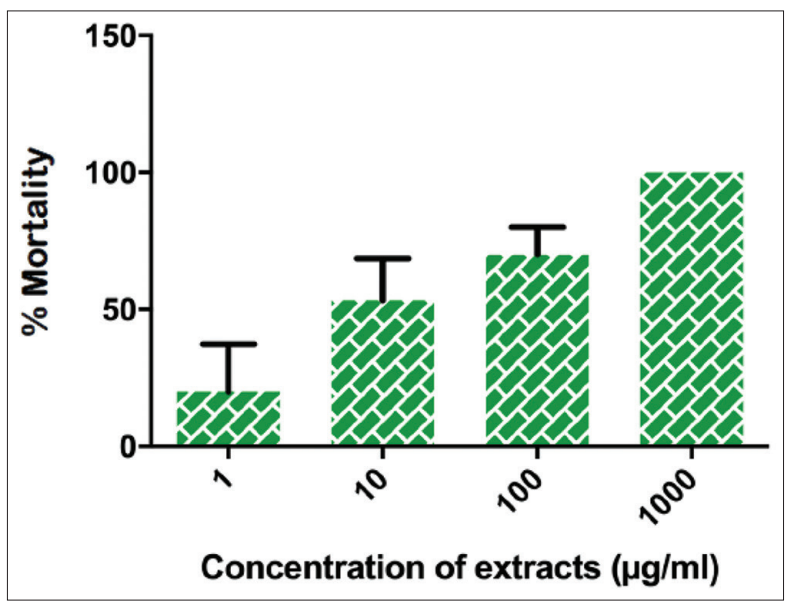

Figure 2: Percentage mortality of Sida acuta whole plant methanol extract (SAM) on $A$. salina nauplii

Table 1: Percentage mortality of shrimp nauplii after $24 \mathrm{~h}$ post exposure to the Sida acuta whole plant aqueous extract (SAA)

\begin{tabular}{|c|c|c|c|c|c|c|c|c|c|}
\hline \multirow[t]{2}{*}{ SI. No } & \multirow[t]{2}{*}{ Conc. of Plant extract (ppm or $\mu \mathrm{g} / \mathrm{mL}$ ) } & \multirow[t]{2}{*}{ Log C Conc. } & \multicolumn{3}{|c|}{$\begin{array}{c}\text { Number of Surviving Nauplii } \\
\text { after } 24 \text { hrs } \\
\text { (No. of nauplii taken in each } \\
\text { trial=10) }\end{array}$} & \multirow{2}{*}{\multicolumn{3}{|c|}{ Mean \pm SD \% Mortality Probit \% Mortality }} & \multirow[t]{2}{*}{$\mathrm{LC}_{50}$} \\
\hline & & & $\mathrm{T1}$ & $\mathrm{T} 2$ & T3 & & & & \\
\hline 1 & 1 & 0 & 2 & 3 & 3 & $2.67 \pm 2.3$ & 73 & 5.61 & $0.75 \pm 1.6 \mu \mathrm{g} / \mathrm{ml}$ \\
\hline 2 & 10 & 1 & 3 & 2 & 1 & $2.00 \pm 3.2$ & 80 & 5.84 & \\
\hline 3 & 100 & 2 & 1 & 2 & 1 & $1.33 \pm 0.5$ & 87 & 6.13 & \\
\hline 4 & 1000 & 3 & 0 & 0 & 0 & $0.00 \pm 0.0$ & 100 & 0 & \\
\hline
\end{tabular}

${ }^{*} \mathrm{~T}=$ Trial; There is no probit value for $0 \%$ and $100 \%$

Table 2: Percentage mortality of shrimp nauplii after $24 \mathrm{~h}$ post exposure to the Sida acuta whole plant methanol extract (SAM)

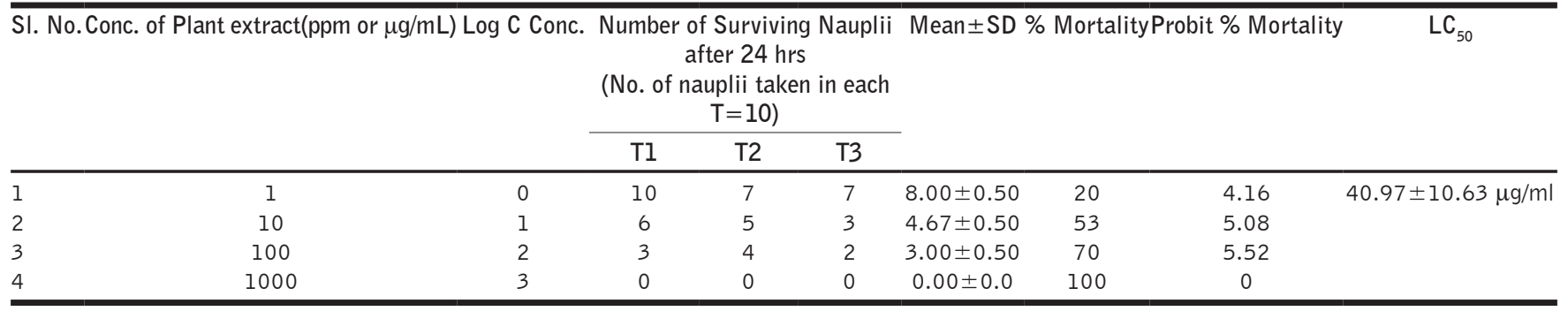

${ }^{*} \mathrm{~T}=$ Trial; There is no probit value for $0 \%$ and $100 \%$ 


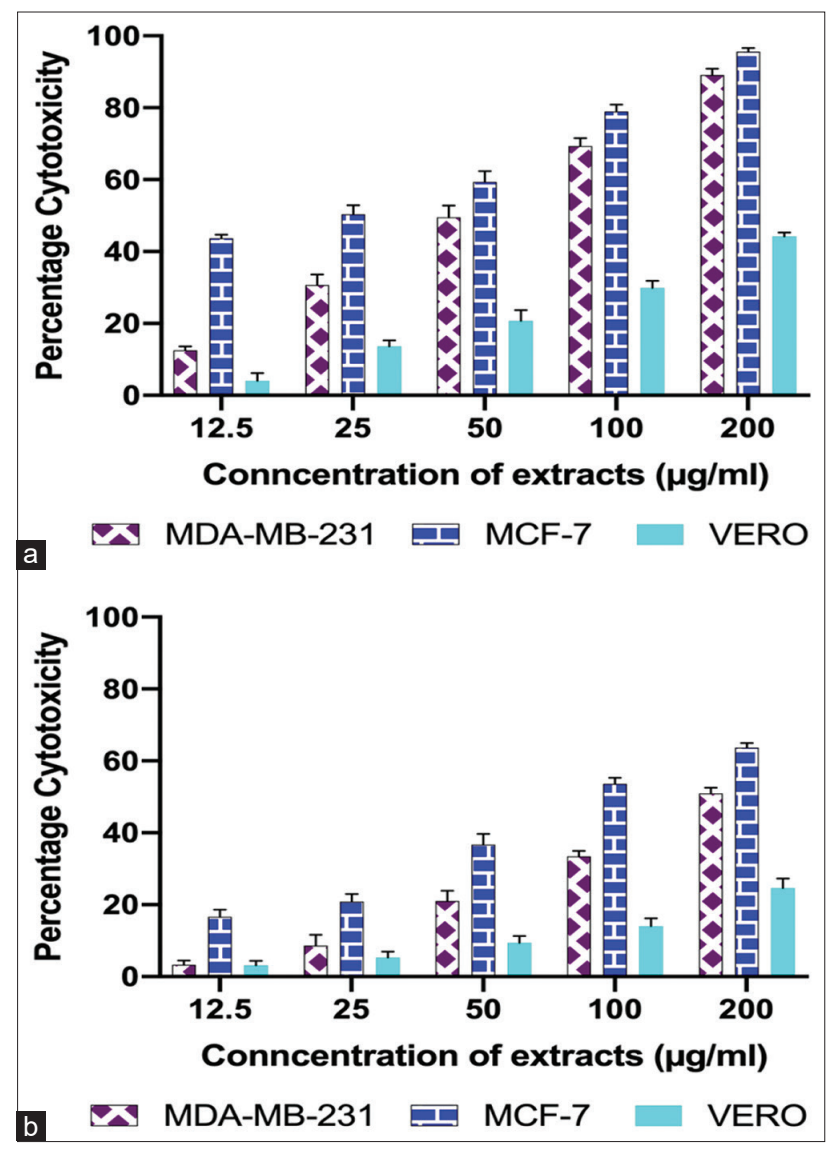

Figure 3: Cytotoxicity of SAA (a) and SAM (b) on MDA-MB-231 and MCF-7 breast adenocarcinoma cells, and VERO normal cell lines
$17.81 \%$ and $4.27 \%$ of late apoptotic cells (UR) and $27.14 \%$ and $37.32 \%$ of early apoptotic cells (LR) respectively (Table 3 ).

\section{DISCUSSION}

Herbal medicines are used for years as the primary source of medical treatment in developing countries. They were well known for their natural antiseptic properties, leading to increased interest for their use in chemotherapy (Sivaraj et al., 2014). World Health Organisation had estimated in 2007 that the drug trade including plant sources were worth US\$100 billion. The trade was predicted to reach US\$5 trillion by 2050 (Rao et al., 2007). Brine Shrimp Lethality Assay is a simple and preliminary assay utilized in the natural products research and is expediently utilized to assess the cytotoxicity of the plant extracts (Meyer

Table 3: Annexin V-FITC and Propidium Iodide expression analysis on MDA-MB-231 and MCF-7 cells upon SAA treatment

\begin{tabular}{lcccc}
\hline Quadrant & $\begin{array}{c}\text { \% of Necrotic } \\
\text { Cells }\end{array}$ & $\begin{array}{c}\text { \% Late } \\
\text { Apoptotic Cells }\end{array}$ & $\begin{array}{c}\text { \% Viable } \\
\text { Cells }\end{array}$ & $\begin{array}{c}\text { \% of Early } \\
\text { apoptotic cells }\end{array}$ \\
\hline Label & UL & $\begin{array}{c}\text { UR } \\
\text { MDA-MB-231 }\end{array}$ & LL & LR \\
Cell & 0 & 0.83 & 98.69 & 0.48 \\
Control & & & & \\
Std Control & 0.89 & 32.11 & 41.55 & 25.45 \\
SAA & 0.78 & 17.81 & 54.27 & 27.14 \\
& & MCF-7 & & \\
Cell & 0.07 & 0 & 99.68 & 0.25 \\
Control & & & & \\
Std Control & 6.13 & 15.07 & 50.3 & 28.5 \\
SAA & 0.7 & 4.27 & 57.71 & 37.32 \\
\hline
\end{tabular}

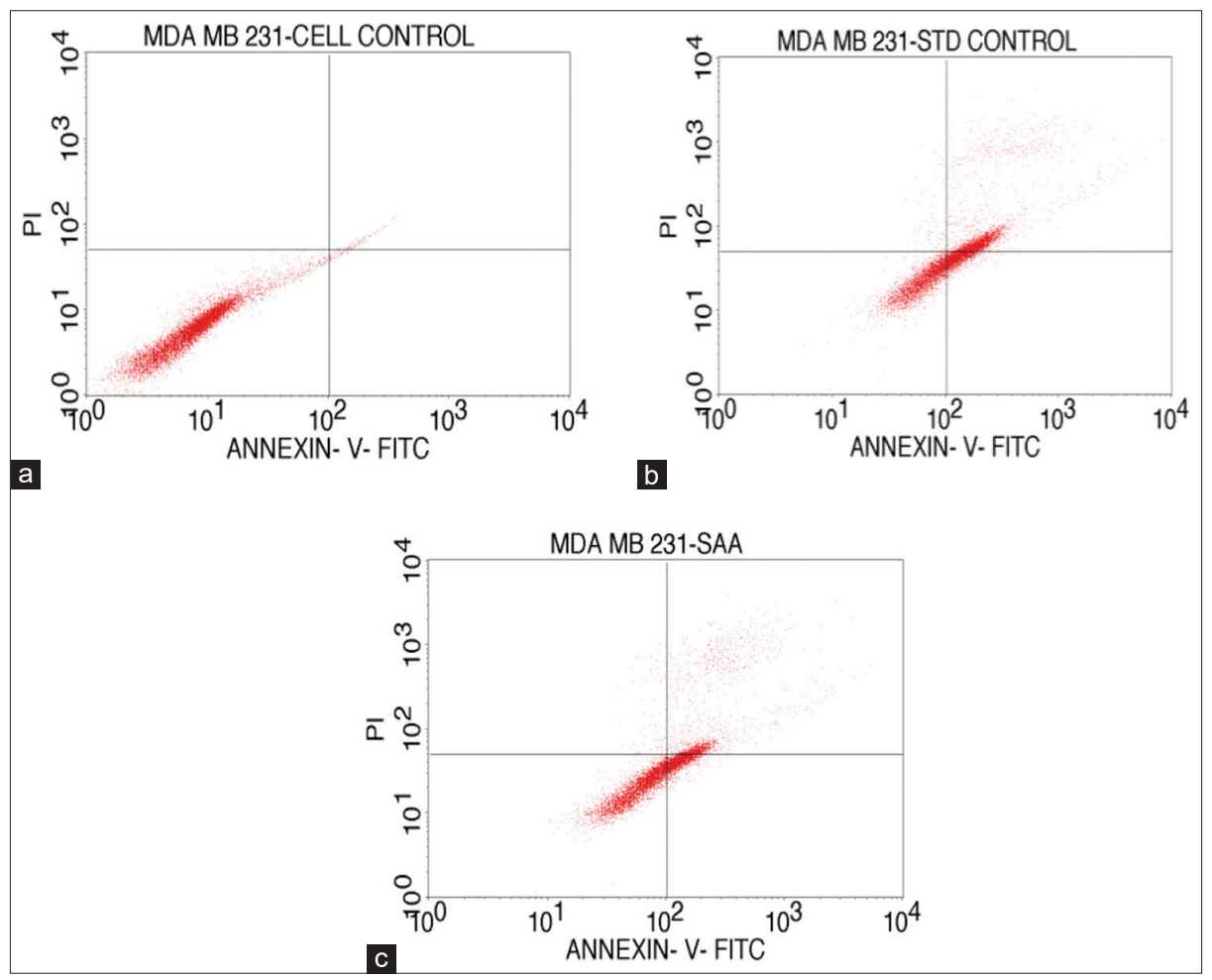

Figure 4: Quadrants showing the untreated (a), Std Control (b) and SAA treated MDA MB 231 cells expressing Annexin V-FITC and Propidium lodide stains analysed using BD FACS calibur, Cell Quest Pro Software (Version: 6.0) 


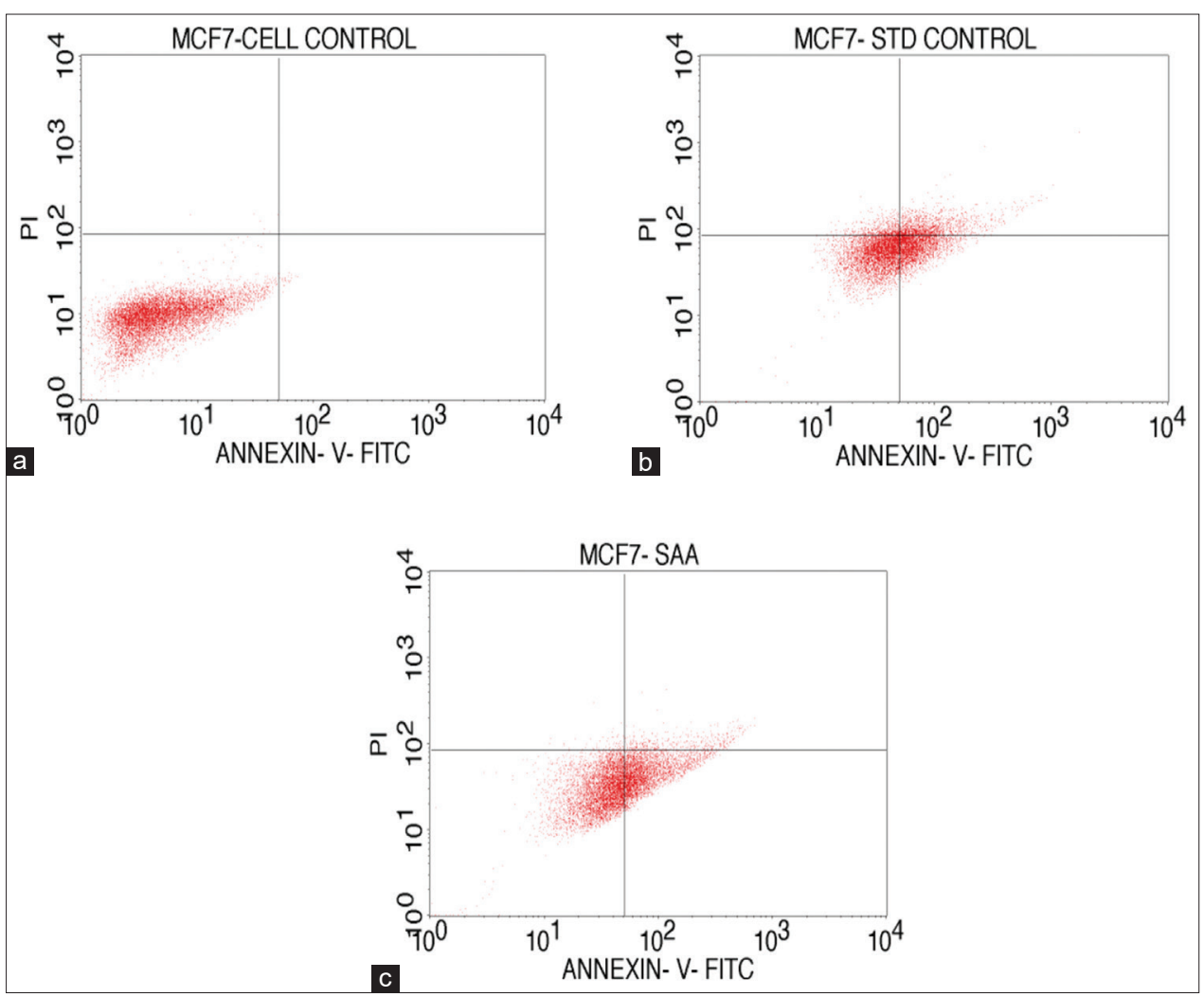

Figure 5: Quadrants showing the untreated (a), Std Control (b) and SAA treated MCF-7 cells expressing Annexin V-FITC and Propidium lodide stains analysed using BD FACS calibur, Cell Quest Pro Software (Version: 6.0)

et al.,, 1982). The advantages of this assay are rapidness, easiness and minimum requirements (Hamidi et al., 2014). As stated by Meyer et al. (1982), $\mathrm{LC}_{50}$ values less than $1000 \mu \mathrm{g} / \mathrm{mL}$, is considered to be toxic and if it is greater than $1000 \mu \mathrm{g} / \mathrm{mL}$ it is said to be non-toxic. The criterion for the toxicity assessment of plant extracts mentioned by Clarkson et al. (2004), denotes that the $\mathrm{LC}_{50}$ values between $0-100 \mu \mathrm{g} / \mathrm{ml}$ are highly toxic, $100-500 \mu \mathrm{g} / \mathrm{ml}$ are medium toxic, $500-1000 \mu \mathrm{g} / \mathrm{ml}$ are low toxic and above $1000 \mu \mathrm{g} / \mathrm{ml}$ is non-toxic. Both extracts tested in this study exhibited high toxicity towards A. salina nauplii with $\mathrm{LC}_{50}$ values of $0.75 \pm 1.6 \mu \mathrm{g} / \mathrm{ml}$ and $40.97 \pm 10.63 \mu \mathrm{g} /$ $\mathrm{ml}$ for aqueous and methanol extracts respectively. According to National Cancer Institute (NCI), America the cytotoxicity criteria is an $\mathrm{IC}_{50}<30 \mu \mathrm{g} / \mathrm{ml}$ for the crude plant extracts in the preliminary test (Suffness \& Pezzuto, 1991). SAA had lower $\mathrm{IC}_{50}$ values in MDA-MB-231 and MCF-7 cells, 50.05 and $22.07 \mu \mathrm{g} /$ $\mathrm{ml}$, close to the reported values by NCI when compared to SAM 184.93 and $94.81 \mu \mathrm{g} / \mathrm{ml}$. Earlier studies on S. acuta demonstrated moderate cytotoxic activity with $\mathrm{IC}_{50}$ values of $41.1,42.3$ and $37.1 \mu \mathrm{g} / \mathrm{ml}$ against BT-20, JURKAT and PC-3 cells respectively (Fadeyi et al., 2013). S. acuta was also reported to inhibit the proliferation of HepG-2 cells (human hepatoma) by $51.62 \%$ at $250 \mu \mathrm{g} / \mathrm{ml}$ (Pieme et al., 2010). However, its effect on breast adenocarcinoma cells has not yet been reported.

Apoptosis is a programmed cell suicide in which cell death naturally occurs during tissue turnover and helps to maintain homeostasis (George et al., 2012). The induction of cytotoxicity by a plant extract alone may not be sufficient to support the existence of anticancer activity. Apoptosis induction is considered as a proof-of-concept approach for identifying a chemopreventive compound and this has always been the accepted approach for exterminating cancer cells (Kumar et al., 2012). Most antineoplastic drugs follow this kind of strategic action (Shawi et al. 2011; Hasan et al., 2011). Flow and image cytometry is a versatile technique through which most of the classical hallmarks of apoptosis can be scrutinized. Hence this technique has become the choice for diverse studies of cellular demise (Wlodkowic et al., 2009). The apoptotic cells can be studied by utilizing a commonly used Annexin V/ PI staining method (Cornelissen et al., 2002). Propidium iodide (PI) in conjunction with Annexin $\mathrm{V}$ is extensively used to determine whether the cells are viable or apoptotic or necrotic by observing the differences in the integrity and permeability of the plasma membrane (Vermes et al., 1995; Vermes et al., 2000). Hence this technique is utilized in this study to examine the efficacy of SAA extract to induce apoptosis. The cytotoxicity results of $S$. acuta aqueous extract was well attributed by the Annexin V/PI flow cytometry analysis. SAA was found to induce apoptosis successfully in MDA-MB-231 and MCF-7 cells. These results were satisfactory in comparison to the standard. Moreover, the results suggest that the extract was more efficient in inducing apoptosis in MCF-7 (ER-positive) cells and less efficient in MDA-MB-231 (ER-negative) cells comparatively.

\section{CONCLUSION}

The study concludes that the extracts exhibited concentration dependent toxicity towards the Brine shrimp, A. salina nauplii 
where the extracts were able to kill all the napulii in its highest concentration. In cytotoxicity studies, the extracts exhibited lower cytotoxicity in normal cells than in cancer cells and were able to induce apoptosis in both the cancer cells examined. Most of the drugs being developed from plant sources had landed successfully in clinical trials. Most importantly their specific cytotoxicity towards cancer cells and non-toxic effects on normal cells put them in high demand. The observations clearly suggest that SAA may have possible therapeutic potential against human breast cancer and specifically against ER-positive breast cancer.

\section{REFERENCES}

Benjumea, D. M., Gómez-Betancur, I. C., Vásquez, J., Alzate, F., GarcíaSilva, A., \& Fontenla, J. A. (2016). Neuropharmacological effects of the ethanolic extract of Sida acuta. Revista Brasileira de Farmacognosia, 26(2), 209-215. https://doi.org/10.1016/j.bjp.2015.09.011

Borris, R. P. (1996). Natural product research. Perspective from a major Pharmaceutical company. Journal of Ethnopharmacology, 51, 29-38. https://doi.org/10.1016/0378-8741(95)01347-4

Clarkson, C., Maharaj, V. J., Crouch, N. R., Grace, O. M., Pillay, P., Matsabisa, M. G., Bhagwandin, N., Smith, P. J., Folb, P. I. (2004). In vitro antiplasmodial activity of medicinal plants native to or naturalized in South Africa. Journal of Ethnopharmacology, 92, 177-191. https:// doi.org/10.1016/j.jep.2004.02.011

Cornelissen, M., Philippe, J., Sitter, D. S., Ridder, D. L. (2002). Annexin $\checkmark$ expression in apoptotic peripheral blood lymphocytes: An electron microscopic evaluation. Apoptosis, 7, 41-47. https://doi. org/10.1023/a:1013560828090

Desai, A. G., Qazi, G. N., Ganju, R. K., El-Tamer, M., Singh, J., Saxena, A. K., Bedi, Y. S., Taneja, S. C., \& Bhat, H. K. (2008). Medicinal plants and cancer chemoprevention. Current Drug Metabolism, 9(7), 581-591. https://doi.org/10.2174/138920008785821657

Fadeyi, S. A., Fadeyi, O. O., Adejumo, A. A., Okoro, C., \& Myles, E. L. (2013). In vitro anticancer screening of 24 locally used Nigerian medicinal plants. BMC Complementary and Alternative Medicine, 13(1), 79. https://doi.org/10.1186/1472-6882-13-79

Finney, D. (1971). Probit analysis, ( $3^{\text {rd }}$ ed.). Cambridge University Press, Cambridge.

George, C. V., Kumar, N. D. R., Suresh, P. K., \& Kumar, A. R. (2012). ApoptosisInduced Cell Death due to Oleanolic Acid in HaCaT Keratinocyte Cells -a Proof-of-Principle Approach for Chemopreventive Drug Development. Asian Pacific Journal of Cancer Prevention, 13, 20152020. https://doi.org/10.7314/apjcp.2012.13.5.2015

Hamidi, M. R., Jovanova, B., \& Panovska, T. K. (2014). Toxic-logical evaluation of the plant products using Brine Shrimp (Artemia salina L.) model. Macedonian Pharmaceutical Bulletin, 60(1), 9- 18. https:// doi.org/10.33320/Maced.Pharm.Bull.2014.60.01.002

Hasan, T. N., Grace, L. B., Shafi, G., Al-Hazzani, A. A., \& Alshatwi, A. A.. (2011). Anti-proliferative effects of organic extracts from root bark of Juglans regia L. (RBJR) on MDA-MB-231 human breast cancer cells: role of $\mathrm{Bcl}-2 / \mathrm{Bax}$, caspases and Tp53. Asian Pacific Journal of Cancer Prevention, 12, 525-530.

Kumar, N. D. R., George, C. V., Suresh, P. K., \& Kumar, A. R. (2012). Cytotoxicity, Apoptosis Induction and Anti-Metastatic Potential of Oroxylum indicum in Human Breast Cancer Cells. Asian Pacific Journal of Cancer Prevention, 13, 2729-2734. https://doi.org/10.7314/ apjcp.2012.13.6.2729

Mclaughlin, J. L., \&Rogers, L. L. (1998). The use of biological assays to evaluate botanicals. Drug Information Journal, 32, 513-524. https:// doi.org/10.1177/009286159803200223

Meyer, B. N., Ferrighi, N. R., Putnam, J. E., Jacobsen, L. B., Nichols, D. E., \& McLaughlin, J. L. (1982). Brine shrimp: A convenient general bioassay for active plant constituents. Planta Medica, 45(5), 31-34. https://doi. org/10.1055/s-2007-971236

Mosmann, T. (1983). Rapid colorimetric assay for cellular growth and survival: Application to proliferation and cytotoxicity assays. Journal of Immunological Methods, 65(1-2), 55-63. https://doi. org/10.1016/0022-1759(83)90303-4

Pieme, C. A., Penlap, V. N., Ngogang, J, \& Costache, M. (2010). In-vitro cytotoxicity and antioxidant activities of five medicinal plants of Malvaceae family from Cameroon. Environmental Toxicology and Pharmacology, 29, 223-228. https://doi.org/10.1016/j. etap.2010.01.003

Rao, R. B. R., Singh, K., Sastry, K. P., Singh, C. P., Kothari, S. K., Rajput, D. K., \& Bhattacharya, A. K. (2007). Cultivation Technology for Economically Important Medicinal Plants. In: K. J. Reddy, B. Bahadur, B. Bhadraiah, M. L. N. Rao (Eds.), Advances in Medicinal Plants (Chap.10, pp.112-122) University Press (India) Private Limited, Hyderabad, India.

Shawi, A. A., Rasul, A., Khan, M., Iqbal, F., \& Tonghui, M. (2011). Eupatilin: A flavonoid compound isolated from the Artemisia plant, induces apoptosis and G2/M phase cell cycle arrest in human melanoma A375 cells. African Journal of Pharmacy and Pharmacology, 5(5), 582-588. https://doi.org/10.5897/AJPP11.079

Sivaraj, R., Rahman, P. K., Rajiv, P., Narendhran, S., \& Venckatesh, R. (2014). Biosynthesis and characterization of Acalypha indica mediated copper oxide nanoparticles and evaluation of its antimicrobial and anticancer activity. Spectrochimica Acta Part A: Molecular and Biomolecular Spectroscopy. 129, 255-258. https://doi.org/10.1016/j. saa.2014.03.027

Suffness, M., \& Pezzuto, J. M. (1991). Assays related to cancer drug discovery. In: K. Hostettmann (Ed.), Methods in Plant Biochemistry: Assays for Bioactivity. (Vol. 6, pp. 71-133) London: Academic Press.

Vermes, I., Haanen, C., \& Reutelingsperger, C. (2000). Flow cytometry of apoptotic cell death. Journal of Immunological Methods, 243(1-2), 167-190. https://doi.org/10.1016/s0022-1759(00)00233-7

Vermes, I., Haanen, C., Steffens-Nakken, H., \& Reutelingsperger, C. (1995). A novel assay for apoptosis. Flow cytometric detection of phosphatidylserine expression on early apoptotic cells using fluorescein labeled Annexin V. Journal of Immunological Methods, 184(1), 39-51. https://doi.org/10.1016/0022-1759(95)00072-i

Wlodkowic, D., Skommer, J., \& Darzynkiewicz, Z. (2009). Flow cytometrybased apoptosis detection. Methods in Molecular Biology, 559, 19-32. https://doi.org/10.1007/978-1-60327-017-5 2 